\title{
Effects of Integrated Soil and Water Conservation Practices on Woody Species Diversity, Structure and Regeneration in Southern Ethiopia
}

\author{
Dessale Wasie ${ }^{1}$, Fantaw Yimer ${ }^{2}$ \\ ${ }^{1}$ Department of Soil and Water Resource Management, College of Agriculture, Woldia University, Mersa, Ethiopia \\ ${ }^{2}$ School of Natural Resources and Environmental Studies, Wondo Genet College of Forestry and Natural Resources, Hawassa University, \\ Shashemanne, Ethiopia
}

Email address:

dessewasie@gmail.com(D. Wasie), fantawyimer2003@gmail.com(F. Yimer)

\section{To cite this article:}

Dessale Wasie, Fantaw Yimer. Effects of Integrated Soil and Water Conservation Practices on Woody Species Diversity, Structure and Regeneration in Southern Ethiopia. Journal of Water Resources and Ocean Science. Vol. 9, No. 4, 2020, pp. 77-86.

doi: $10.11648 /$ j.wros.20200904.12

Received: August 6, 2020; Accepted: September 3, 2020; Published: September 14, 2020

\begin{abstract}
Land degradation in the form of soil erosion is one of the most serious problems in the worldwide. Physical and biological soil and water conservation measures implemented by various land rehabilitation program is the best option to address this problem. This study was conducted to evaluate the effect of integrated soil and water conservation (SWC) practices on Woody Species Diversity, Structure and Regeneration in Southern Ethiopia. A total of 60 plots (3 land use*4 transect*5 quadrants), measuring $20 \mathrm{~m} * 20 \mathrm{~m}$ each, were established along transect line laid for woody vegetation data collection. Woody species diversity in the study sites were determined using the Shannon (H') and Simpson diversity index through the analysis of species richness and evenness of species. A total of 28 woody species, belonging to 15 families were identified. The diversity, richness, density and basal area of woody species were significantly higher in closure area with SWC $(\mathrm{p}<0.05)$ compared to the value in closure area without SWC and open grazing land. The inverted 'J' shaped distribution of height and DBH exhibited in closure area with SWC, which has more potential to enhance vegetation regeneration. The findings generally confirmed that area closure with SWC practices was highly improved woody species diversity, structure and regeneration status. Accordingly, to improve the biophysical conditions of degraded hillside areas implementing of area closure with integrated SWC practices is a best option.
\end{abstract}

Keywords: Area Closure, Rehabilitation, Soil and Water Conservation, Soil Erosion, Species Diversity, Woody Vegetation

\section{Introduction}

Environmental deterioration has now become one of the most serious problems confronting mankind. Among these problems, land degradation is a serious global environmental problem [1]. Around 5-10 million ha (0.36-0.71\%) of the world's arable land seriously degraded, where $80 \%$ of this degradation caused by soil erosion [1]. Almost all inhabited lands in Sub-Sahara Africa (SSA) are prone to land degradation [2].

The extreme dependence of Ethiopian rural population on natural resources, particularly land, as a means of livelihood makes Ethiopian vulnerable for land resources degradation leading to decline in productivity [3]. This has significant impacts on ecosystem services, crop production, downstream flooding and reservoir sedimentation and economic costs [4]. According to [5] in Ethiopia, soil conservation measures play a great role to achieve sustainable development of its agricultural sector and the economy at large. Area closure with soil and water conservation practices is the best among the various techniques used for rehabilitation of degraded hillside area [6]. Therefore, soil conservation practices are an essential part of the system for reducing erosion during critical times of the year, conservation of soil moisture and restoration of vegetation cover [7].

The Ethiopia highlands and particularly Hawassa Zuriya Woreda are prone to land degradation due to its rugged 
topographic features, climate, and anthropogenic impacts such as deforestation, uncontrolled grazing and agricultural practices. Due to this degradation nutrient rich to soil was loss and thereby crop yield become reduced. Similarly, rapid runoff would reduce recharge of ground water, siltation and rapid decrement of the storage capacity of Lake Hawassa. Accordingly, the risk of soil erosion has continued and will persist as a serious threat to farmers 'livelihoods and economic development in the area [8].

A project known as "Degraded land rehabilitation as a base of sustainable management of natural resources in Hawassa Zuriya Woreda, SNNPR" was implemented to solve these problems by Mendel University in Brno Project in Ethiopia, Hawassa. The intentions of the interventions were to reduce soil erosion, restore soil fertility, rehabilitate degraded lands, improve micro-climate and agricultural production and productivity and restore environmental condition. However, there has not been any research conducted to evaluate the effect of integrated soil and water conservation practices on Woody Species Diversity, structure and Regeneration. Therefore, the main objective of this study was to evaluate the effect of integrated soil and water conservation practices on Woody Species Diversity, structure and Regeneration in
Hawassa Zuriya Woreda, southern Ethiopia.

\section{Materials and Methods}

\subsection{Description of the Study Area}

The study was conducted in Hawassa Zuriya Woreda, Sidamo Zone, Southern Ethiopia. Geographically, it is located between $6^{\circ} 58^{\prime} 30^{\prime \prime}$ and $7^{\circ} 8^{\prime} 0^{\prime \prime} \mathrm{N}$ latitude; and $38^{\circ}$ $11^{\prime} 0^{\prime \prime}$ and $38^{\circ} 27^{\prime} 0^{\prime \prime} \mathrm{E}$ longitude (Figure 1). In terms of agroclimatic zone, the study area falls within dry woina-dega (mid altitude) category [8]. The average annual precipitation (1987 to 2016) in Hawassa station, near the study area, is about $953 \mathrm{~mm}$. The annual rainfall ranges between 950 to $1400 \mathrm{~mm}$. The mean monthly rainfall is above $100 \mathrm{~mm}$ from April to September with May showing the highest mean monthly rainfall at $122 \mathrm{~mm}$. The months with the lowest rainfall are November, December and January. For the last 29 years, the highest rainfall of $1197 \mathrm{~mm}$ was recorded in 2006 and lowest is $670 \mathrm{~mm}$ in 2015. The temperature is relatively constant throughout the year with average temperature of $18.5^{\circ} \mathrm{C}[8]$.

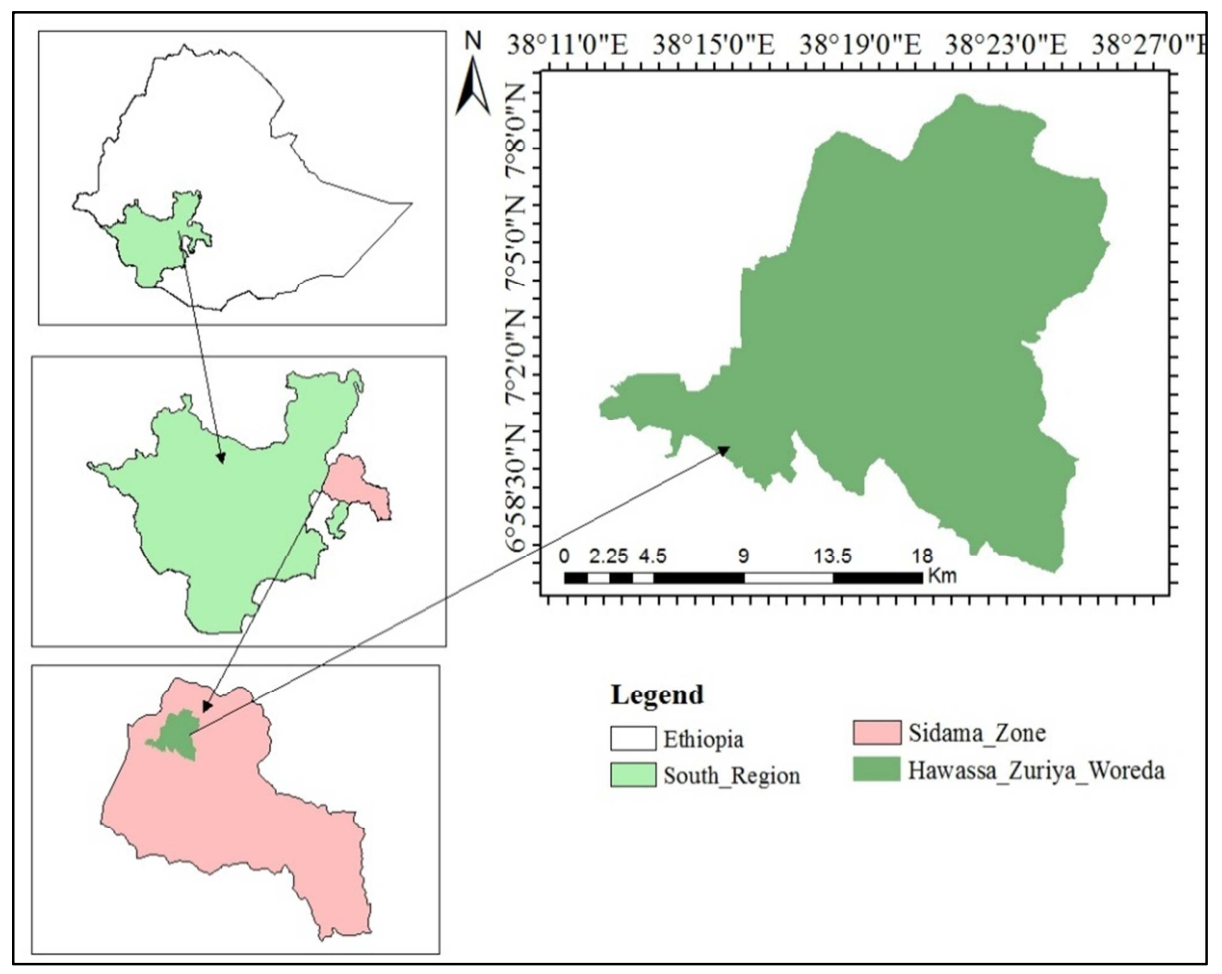

Figure 1. Location of study site.

Well drained Eutric Cambisols are the dominant soil types in the area. The soils are very poor to excessively drained, moderately deep to very deep, fine to medium textured [6]. The mean altitude of the study area is $1,965 \mathrm{~m}$ above sea level. The major landform in the study site includes flat, gentle slopping to undulating and rolling hills and mountains with slope ranging from level $(0 \%)$ to very steep slope $(\geq$ $30 \%$ ) [8]. The major land use includes grass land with shrubs, grassland for grazing not under cultivation, bare surface with degraded grass cover and limited vegetation along drainage lines [8].

The natural vegetation in the area is characterized as dry afro montane vegetation occurring at higher altitudes of the hilly slopes; and lowland acacia woodlands occurring at the lower landscape of the hilly sides. The woodlands in the highlands have remnant tree of high forest species, which were sparsely 
distributed. The major woody species dominating the area are acacia species, Albiziagummifera, Albiziaschimperiana, Balanitesaegyptiaca, Croton macrostachyus, Ficussycomorus, Maytenusundata, Rhusnatalensis[9].

\subsection{Vegetation Sampling and Data Collection}

A reconnaissance survey of study area was undertaken in the first week of November 2017 to get the general overview of the area. For the purpose of this study, parts of the closure area with SWC, closure area without SWC and open grazing land, which have the same topographic, soil parent material, climatic characteristics and history but with different management intervention were selected. The open grazing land was included for the purpose of comparison as a control.
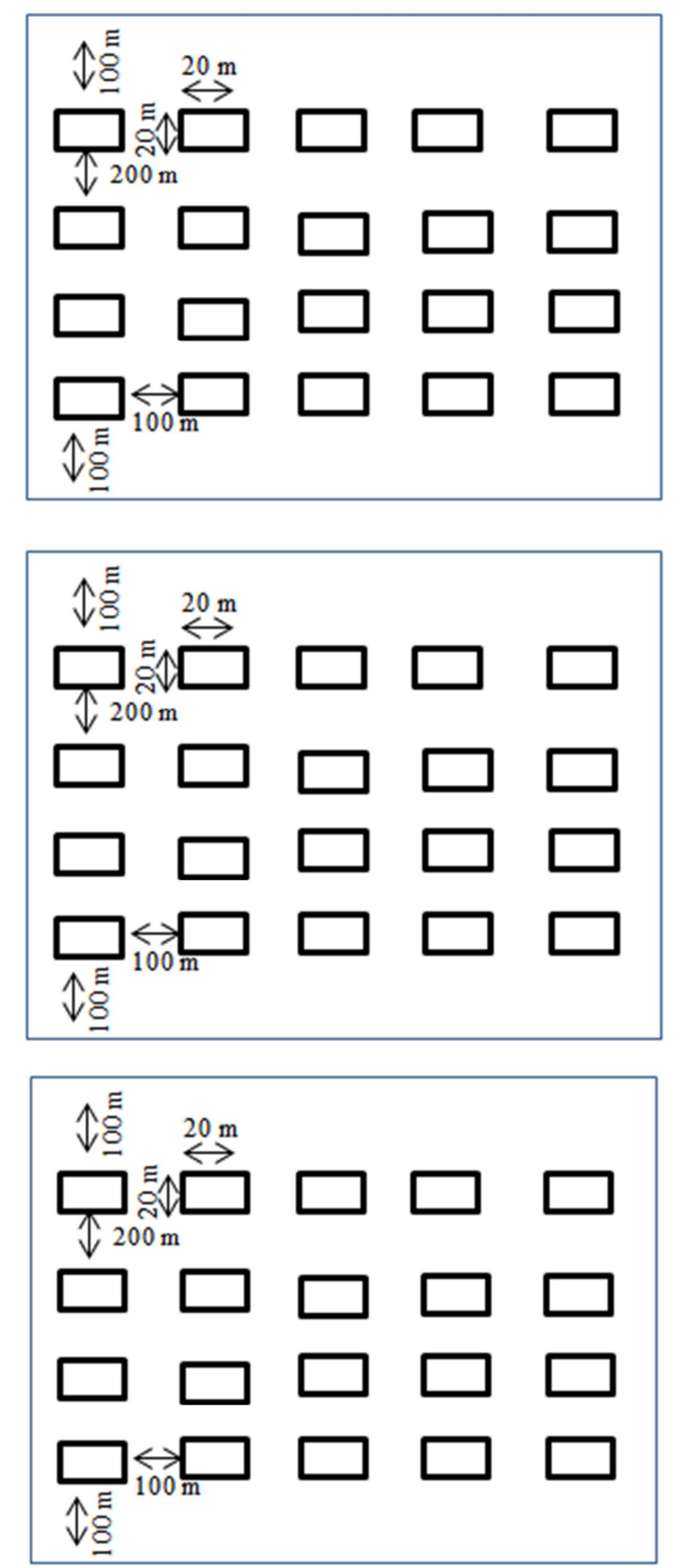

Figure 2. Vegetation Sampling plot at three adjacent sub catchments.
Transects were systematically laid in South North direction parallel to each other following the contour to collect primary data on the status of woody vegetation's from each sites. At each land management units, transects were laid at $200 \mathrm{~m}$ interval with length of $2 \mathrm{~km}$, but modified to exclude nontargeted habitats (e.g. rivers, gullies). The first and last transect lines were laid at a distance of $100 \mathrm{~m}$ from the edges to avoid the effect of disturbances. A total of 12 transect lines (4 transect*3 land management units), and 60 sampling quadrants (4 transect*3 land management units* 5 sample plots) each with a size of $20 \mathrm{~m} * 20 \mathrm{~m}$ were established for vegetation inventory at $100 \mathrm{~m}$ interval (Figure 2). The first transect line and quadrate was laid out randomly, and the rest were systematically by using GPS. Quadrate sizes of $20 \mathrm{~m} \mathrm{x}$ $20 \mathrm{~m}$ were used as being more sustainable for low density of woody vegetation in those areas [6]. The total sampled area was 16 ha, which constituted $29 \%$ of the total study area.

In each quadrat all woody vegetation categories were identified, counted and recorded by their local and /or scientific names using a field guide of [13]. Key informants were used to provide local names of the encountered woody species through researcher's experience. They were selected by snowball method. The total numbers of KI involved in this study were five from each study sites. The height and diameter of mature plants (height $>2 \mathrm{~m}$ and $\mathrm{DBH}>2.5 \mathrm{~cm}$ ) and saplings (height $1-2 \mathrm{~m}$ and $\mathrm{DBH}<2.5 \mathrm{~cm}$ ) [10] were measured by using clinometer and caliper respectively. For multiple stems trees and shrubs, the circumference was measured separately and averaged. In the case of Seedlings (height $<1 \mathrm{~m}$ ), the number of individuals were recorded only by their counts.

For species that were difficult to identify in the field, Voucher specimen representatives of woody vegetation's were collected, pressed, dried and transported to the National Herbarium in the Department of Biology, Addis Ababa University, for proper identification. The nomenclature of plant species was carried out using the published Flora of Ethiopia and Eriteria [11].

\subsection{Vegetation Data Analysis}

Woody species diversity in the study sites were determined using the Shannon $\left(\mathrm{H}^{\prime}\right)$ and Simpson diversity index through the analysis of species richness and evenness of species. Species richness is the total number of species in the community [12]. Similarly, the abundance of each woody species defined here as the total numbers of all individuals of a species in all the quadrats.

Shannon diversity index were calculated as:

$$
H^{\prime}=-\sum_{i=1}^{S} p i \ln p i
$$

Where: $\mathrm{H}^{\prime}=$ Diversity of species $\mathrm{S}=$ Number of species $\mathrm{Pi}=$ the proportion of individual's abundance of the $\mathrm{i}^{\text {th }}$ species $\ln =$ long base $n$.

Simpson's diversity index was calculated as:

$$
\mathrm{D}=1-\sum_{\mathrm{i}=1}^{s} \frac{\mathrm{n}_{\mathrm{i}}\left(\mathrm{n}_{\mathrm{i}}-1\right)}{\mathrm{N}(\mathrm{N}-1)}
$$


Where: $\mathrm{D}=$ Simpson index, $\mathrm{n}=$ the total number of organisms of a particular specie, $\mathrm{N}=$ the total number of organisms of all species. According to [14], equitability was calculated using the Shannon evenness index following the equation:

$$
\text { Equitability }(\mathrm{J})=\frac{H^{\prime}}{H \max }=-\frac{\sum_{i=1}^{x} p i \ln p i}{\ln s}
$$

Where: $\mathrm{H}^{\prime}$ max=ln $\mathrm{S}, \mathrm{H}^{\prime}=$ Shannon diversity index, In $\mathrm{S}=$ the natural logarithm of the total number of species in each community, $\mathrm{S}=$ number of species in each community.

The Sorensen's similarity coefficient was computed to determine the patterns of species turnover among successive communities. It is used to measure similarities between two habitats and described using the following formula [15].

$$
S_{s}=\frac{2 a}{2 a+b+c}
$$

Where: $\mathrm{a}=$ number of species common to both habitats $\mathrm{b}=$ number of species present in the first habitat but absent in the second $\mathrm{c}=$ number of species present in the second habitat but absent in the first.

To determine vegetation structure, parameters like species density, frequency, tree height, diameter at breast height (DBH), abundance, basal area, and importance value index (IVI) were calculated as follows [15].

Density $=$ number of individuals in the sample plots/ sample area

Relative density=Density of species $* 100 /$ total density of all species

Frequency $(\mathrm{F})=$ number of plots in which a species occurred/ total number of plots

Relative frequency=Frequency of a specie $* 100 /$ total frequency of all species.

Basal area calculations were made on the diameter measurements the stem with DBH of $>2.5 \mathrm{~cm}$. It is expressed in square meter/hectare.

$\mathrm{BA}=\pi(\mathrm{d} / 2)^{2}$, where $\mathrm{d}=\mathrm{DBH}, \pi=3.14$

Relative dominance $=$ Do of a specie $* 100 /$ total Do of all species. Where; Dominance (Do) is average basal area per Tree times the number of Tree species.

Importance value index (IVI) was calculated by summing up relative frequency $(\mathrm{RF})$, relative density $(\mathrm{RD})$ and relative dominance (RDO) values.

The regeneration status was analyzed by histogram constructed using distribution of individuals into different diameter and height classes. Categorized into four diameter and height classes [6]. Moreover, regeneration status was analyzed by comparing saplings and seedlings with the matured trees categorized as: Good: seedlings >saplings >adults; Fair: seedlings $>$ or $\leq$ saplings $\leq$ adults; Poor: saplings may be $<$, $>$ or=adults; none: only adult and new: if a species has no mature, but only sapling and/or seedling stages [16].

\subsection{Statistical Analysis}

The impact of SWC practices on different vegetation parameters were statistically tested by using Statistical
Package for Social Sciences (SPSS) version 16 following the procedure of one-way ANOVA. Mean comparisons were performed by using Tukey HSD test with $\mathrm{p}<0.05$.

\section{Results and Discussion}

\subsection{Effects on Woody Species Composition and Diversity}

A total of 28 woody species, belonging to 15 families were counted and recorded in the three land management units. Among these woody species, trees, shrubs and tree/shrubs constituted 15, 6 and 7 species respectively. The highest number of woody species was recorded in closure area with SWC (26), followed by closure area without SWC (17) and open grazing land (7), of these, 6 species were common to all land management units (Table A1). The numbers of families in open grazing land, closure area without SWC and closure area with SWC were represented by 4,8 and 15 families respectively. Among the families, Fabaceae was the most diverse and dominant family in number of species as well as in individual composition represented with 12 species. Sapindaceae and Tiliaceae were the second diverse families represented with 2 species and the rest 11 families were represented with only one tree/shrub species each (Table A1).

The average species richness was significant different $(\mathrm{P}<0.05)$ among the three study sites, higher in closure area with SWC followed by closure area without SWC and open grazing land (Table 1). This showed that closure area with SWC was more enriched with vegetation composition than closure area without SWC and open grazing land. This study result agrees with studies conducted in other part of the country by [6]; showed that, area closure with SWC boosting the species composition and allowed regeneration of shrubs and trees in the area. While, the species composition of open grazing land was lower than closure area without SWC. This may be due to interference and modification by humans in open grazing lands that declined the species composition. Study conducted by [17] reported that, human induced disturbance and animal grazing have a strong negative effect on species composition, seed germination, and seedling growth and in turn results in less species richness.

The mean Simpson diversity indices, species evenness and dominance did not significantly different between closure area with SWC and closure area without SWC but both significantly differed from open grazing land $(\mathrm{P}<0.05)$. The Shannon diversity indices was significantly different among the three study sites $(\mathrm{P}<0.05)$. Diversity indices and species evenness were higher in closure area with SWC followed by closure area without SWC and open grazing land (Table 1). These values indicate that, there were better and more divers species in closure area with SWC than open grazing land and closure area without SWC. While, 
species dominance for open grazing land was significantly higher $(\mathrm{p}<0.05)$ than closure area without SWC followed by closure area without SWC (Table 1),

Table 1. Woody species richness, evenness and diversity in relation to management intervention (mean $\pm S E$ ). indicating that few species were dominant in the open grazing land and closure area without SWC.

\begin{tabular}{llllll}
\hline \multirow{2}{*}{ Land use } & \multicolumn{2}{l}{ Vegetation parameters } & & \\
\cline { 2 - 6 } & Dominance & Richness & Simpson & Shannon & Evenness \\
\hline Open grazing & $0.796 \pm 0.05^{\mathrm{a}}$ & $1.7 \pm 0.17^{\mathrm{a}}$ & $0.203 \pm 0.05^{\mathrm{a}}$ & $0.321 \pm 0.08^{\mathrm{a}}$ & $0.387 \pm 0.09^{\mathrm{a}}$ \\
Closure area without SWC & $0.393 \pm 0.03^{\mathrm{b}}$ & $4.55 \pm 0.35^{\mathrm{b}}$ & $0.606 \pm 0.03^{\mathrm{b}}$ & $1.172 \pm 0.08^{\mathrm{b}}$ & $0.781 \pm 0.03^{\mathrm{b}}$ \\
Closure area with SWC & $0.293 \pm 0.02^{\mathrm{b}}$ & $7.4 \pm 0.41^{\mathrm{c}}$ & $0.706 \pm 0.03^{\mathrm{b}}$ & $1.547 \pm 0.08^{\mathrm{c}}$ & $0.8 \pm 0.02^{\mathrm{b}}$ \\
\hline
\end{tabular}

This variation in species diversity may be due to the result of SWC practice increase plant available water and improved soil physical and chemical properties in closure area with SWC by increasing biomass production. Moreover, it may be due to their vulnerability to disturbances, the diversity of woody vegetation mainly seedlings became very diminutive in open grazing land. Study by [18], found that the closure area has more diverse, evenly distributed and with relatively related abundance of all individual plant species compared to the open site. Similarly, study results reported by [6], showed that low evenness of woody species in open grazing lands reveals that the areas are dominated with few species and this could be attributed to excessive disturbance and selective cutting of some species by humans resulted in dominance of few species. Hence, dominance is inversely related to evenness, the open sites are considered to be with less species diversity than closure area [17].

\subsection{Similarity of Woody Species}

The Sorensen's similarity coefficient (SSC) between closure area with SWC and without SWC and closure area without SWC and open grazing were $069 \%$ and $58 \%$ respectively, showed moderate similarity coefficient. While, the SSC between closure area with SWC and open grazing land $42 \%$ was lower similarity coefficients (Table 2 ).

Table 2. Sorensen's similarity coefficient of study sites.

\begin{tabular}{llll}
\hline & Open grazing & CA without SWC & CA with SWC \\
\hline Open grazing & 1 & & \\
CA without SWC & 0.58 & 1 & \\
CA with SWC & 0.42 & 0.698 & 1 \\
\hline
\end{tabular}

This result indicates there is higher variation between closure area with SWC and open land may be due to the positive impact of management supported the closure area with SWC to be enriched in species composition. This is in line with studies conducted by [6], concluded that due to difference in management, there are greater variation between closure area with SWC and open grazing land because of change in species type and composition.

\subsection{Structure of Woody Species and Regeneration Status}

\subsubsection{Density, Frequency and Basal Area of Woody Species}

The mean density and basal area of woody vegetation for closures area with SWC were significantly different from that of closure area without SWC and open grazing land ( $p$ $<0.05$ ). While, there were no significance different between closure area without SWC and open grazing land ( $p>0.05)$. The density and basal area of woody species were higher in closure area with SWC followed by closure area without SWC and open grazing land (Table 3). This variation was due to the effect of SWC increases water use efficiency of plants by conserving rain water which increase soil moisture which leads to soil seed germination, higher survival rate of emerged seedlings and promote woody vegetation density.

Table 3. Woody species density per ha and basal area $(\mathrm{m} 2 / \mathrm{ha})$ in study sites (mean $\pm S E$ ).

\begin{tabular}{lll}
\hline Land use type & No of individuals $/ \mathbf{h a}$ & $\mathbf{B A}\left(\mathbf{m}^{\mathbf{2}} / \mathbf{h a}\right)$ \\
\hline Open grazing & $152.5 \pm 27.9^{\mathrm{a}}$ & $1.21 \pm 0.32^{\mathrm{a}}$ \\
Closure area without SWC & $336.25 \pm 38.2^{\mathrm{a}}$ & $2.55 \pm 0.46^{\mathrm{a}}$ \\
Closure area with SWC & $966.25 \pm 138.7^{\mathrm{b}}$ & $6.34 \pm 1.07^{\mathrm{b}}$ \\
\hline
\end{tabular}

*Means with different superscript letters are significantly different $(\alpha<0.05)$

Similarly, [19] reported that area closures with SWC on degraded hill-slope areas resulted in increased density of woody species. Unlike the density of woody species, basal area is a function of size of the woody species stems than simple stem counts. Hence, the majority of the basal area of the woody species was accounted by woody species having a diameter at breast height exceeding $30 \mathrm{~cm}$. This shows that higher diameter class vegetation's were higher in closure area with SWC measures than open grazing land, which mean there were high vegetation growth rate in closure area with SWC. This is agreed with the study result reported by [6] found that, the mean basal area of the woody species was higher in closure area with SWC measures and lower in the open grazing land.

The frequency distribution of species in closure area with SWC and closure area without SWC were decreased towards higher frequency classes. Whereas, in open grazing land frequency distribution of species increased along with increase in frequency classes (Figure 3).

The frequency distribution of vegetation indicates the heterogeneity or homogeneity of a community [20]. Accordingly, the woody vegetation frequency distribution in closure area with SWC and without SWC showed inverted $\mathrm{J}$ shape pattern of distribution (Figure 3), indicating high degree of floristic heterogeneity [21]. 
Whereas, the frequency distribution of vegetation in open distribution (Figure 3), representing similar floristic grazing lands showed normal $\mathrm{J}$ shape pattern of composition (homogeneity) [20] in the area.

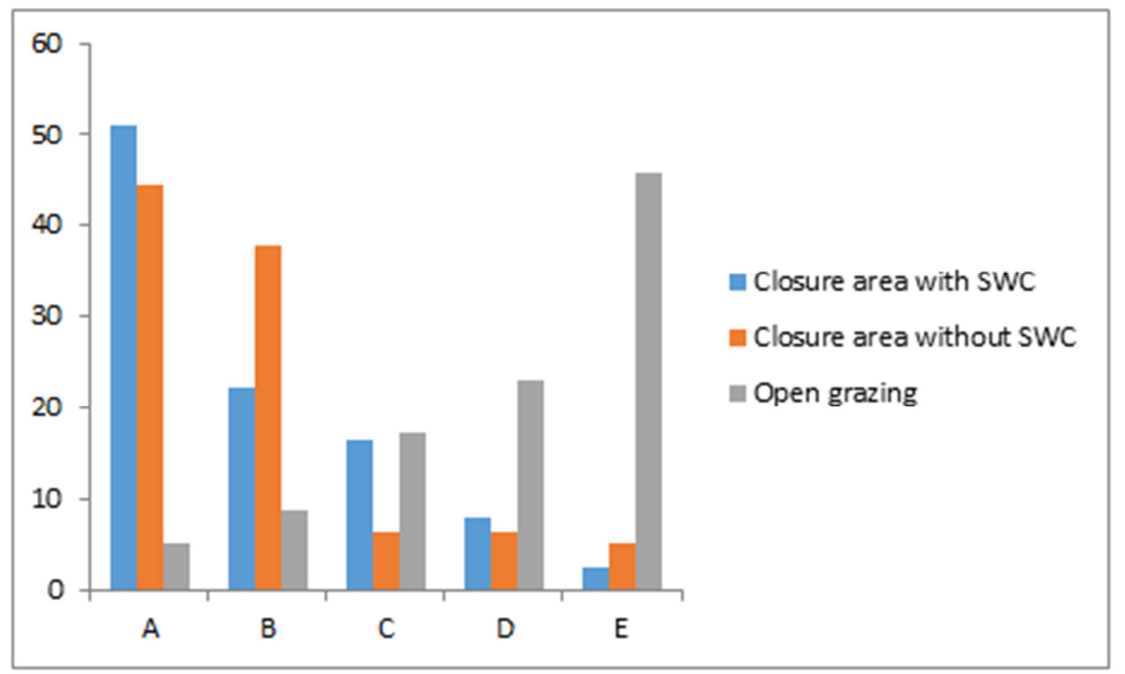

Figure 3. Frequency distribution of woody species.

\subsubsection{Importance Value Index (IVI)}

The top three important woody species in closure area with SWC that account more than half of IVI value were Eucalyptus camaldulensis, Dodonaea viscosa and Acacia saligna, the remaining IVI value was from 23 woody species (Table A2). However, the top three important woody species in closure area without SWC that account more than half of IVI value were Acacia tortilis, Olea europeae and Balanites aegyptiaca, the remaining IVI value was from 12 woody species (Table A2). Likewise, in open grazing land; Acacia tortilis, Acacia bussei and dichrostachys cinerea accounts more than $79 \%$ of IVI value, but the remaining IVI value was from 4 woody species. Species with the greatest importance value are the most dominant of particular vegetation and higher value of frequency and density [22].

\subsubsection{Tree Height and $\mathrm{DBH}$}

The tree height analysis result showed that in closure area with SWC and without SWC the majority of total tree height constituted the first height class (height $<2 \mathrm{~m}$ ). The tree height distribution decreased with an increase in height class showing inverted $\mathrm{J}$ shape pattern of distribution (Figure 4). This pattern indicating that both land use vegetation has good reproduction and regeneration potential [18]. This finding is in line with the study result reported by [6], found that Calpurnia aurea contributes most to the lower height class of closure area with SWC; but in this study Dodonaea viscosa contribute a lot.

The DBH distribution analysis of trees showed that the first $\mathrm{DBH}$ class $(\mathrm{DBH} \leq 5 \mathrm{~cm})$ constituted the majorities of tree DBH in closure area with SWC and without SWC. The tree species extremely obstructed in the middle DBH classes in open grazing lands. Therefore, the species distribution followed an inverted $\mathrm{J}$ shape pattern in closure area with SWC and without SWC (Figure 5), showing high rate of regeneration status of tree species in this site [6]. [18] found that the tree species in closure area with SWC showed ongoing recruitment than their adjacent grazing lands.

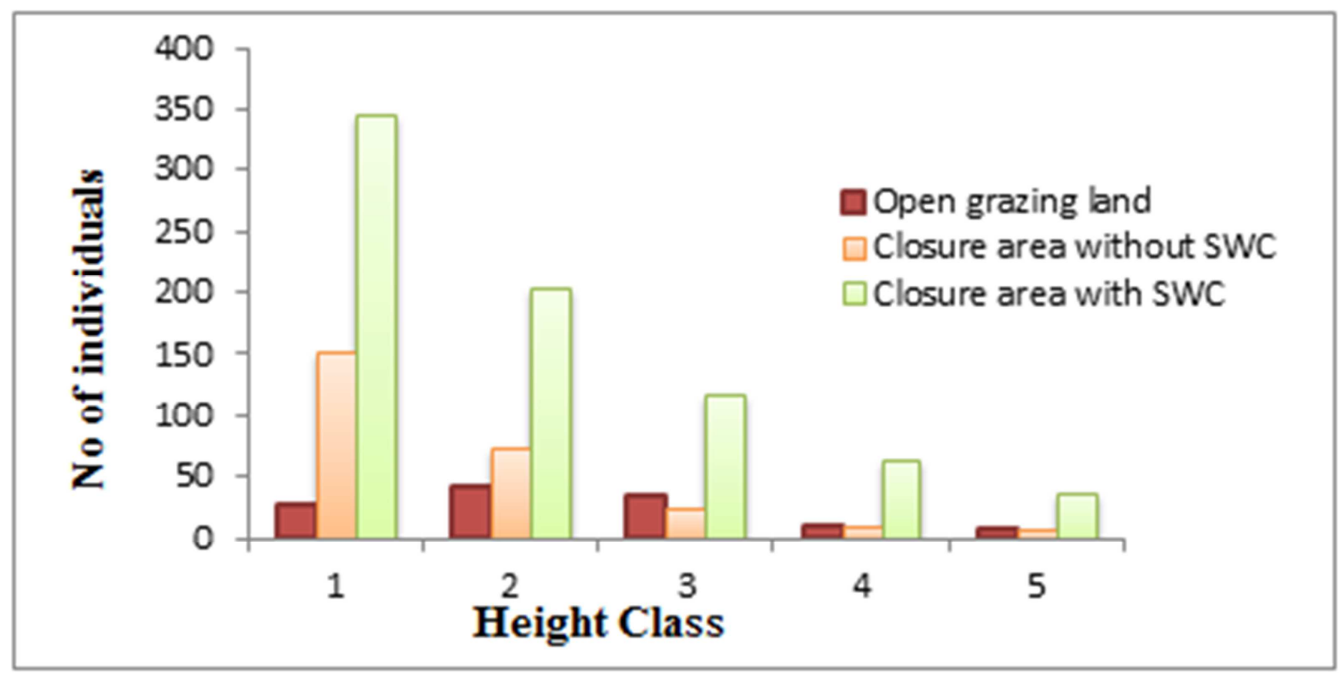

Figure 4. Height class distributions of woody species at study sites (Height class $1 . \leq 2 \mathrm{~m} ; 2.2 .1-5 \mathrm{~m} ; 3.5 .1-10 \mathrm{~m} ; 4$. 10.1-15 m; 5. $\geq 15.1 \mathrm{~m}$ ). 


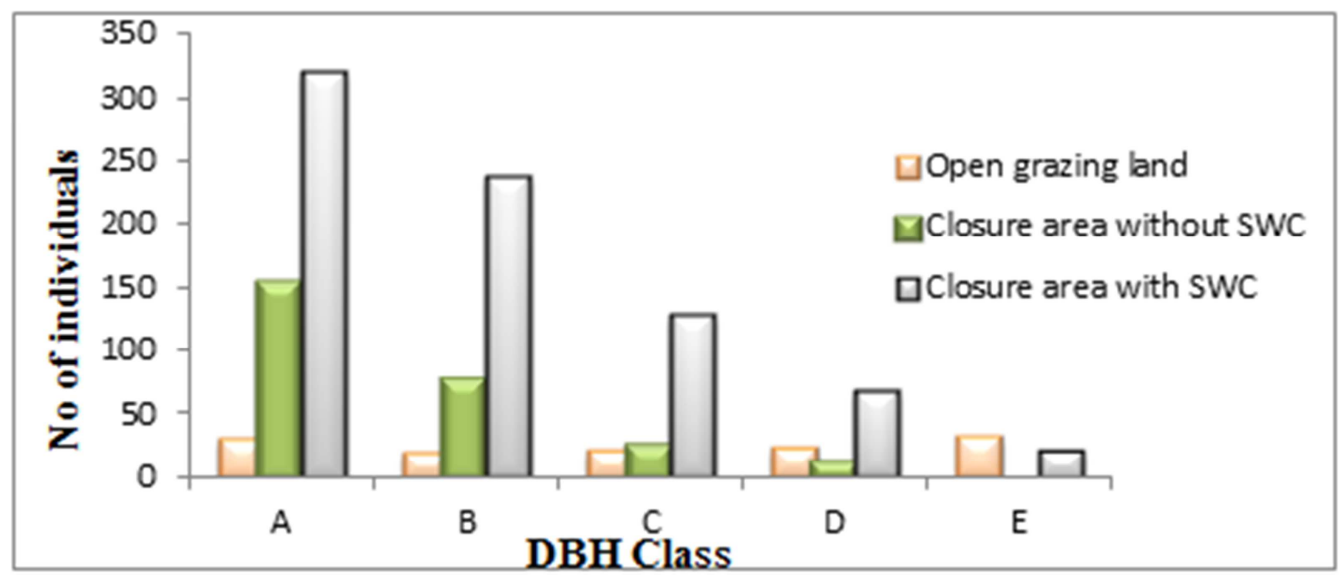

Figure 5. Diameter class distribution of woody species at study site (DBH class $1 . \leq 5 \mathrm{~cm} ; 2.5 .1-10 \mathrm{~cm} ; 3.10 .1-15 \mathrm{~cm} ; 4.15 .1-20 \mathrm{~cm} ; 5 . \geq 20.1 \mathrm{~cm}$ ).

\section{Conclusions and Recommendation}

Conclusion

This study was conducted to assess the impact of integrated soil and water practices on vegetation restoration by comparing the three sub catchments: closure area with SWC, closure area without SWC and open grazing. The results of the study showed that woody species composition, richness, diversity, number of seedling and number of sapling show significant differences $(\mathrm{P}<0.05)$. Majority of woody species of closure area with SWC have better distribution in their individuals than in the closure area without SWC which in turn better than the open grazing land. Sorensen's similarity coefficient also indicated that there is higher variation between closure area with SWC and open grazing land because of change in species type and composition.
These indicate that closure area with SWC have more potential to enhance vegetation regeneration and improve species composition. The present study also clearly indicated that area closures with incorporation of different SWC measures could be possible options to foster the rehabilitation of degraded lands.

Recommendation

The study suggest the following recommendations: Protecting open degraded areas from degradation and promoting indigenous tree plantation and conservation practices are the good options to assist the regeneration of woody species. Since the area has high accelerated erosion, to tackle the problem, there must be need implementation of area closure integrated with various soil and water conservation practices to improve woody vegetation density, diversity and regeneration status.

\section{Appendix}

Table A1. List of species identified in the study site.

\begin{tabular}{llllll}
\hline Botanical Name & Family & category & Open grazing & Closure area without SWC & Closure area with SWC \\
\hline Acacia abyssinica & Fabaceae & $\mathrm{T}$ & + & + & + \\
Acacia bussei & Fabaceae & $\mathrm{T}$ & + & + & + \\
Acacia saligna & Fabaceae & $\mathrm{T} / \mathrm{S}$ & - & - & + \\
Acacia senegal & Fabaceae & $\mathrm{T} / \mathrm{S}$ & + & + & - \\
Acacia seyal & Fabaceae & $\mathrm{T}$ & - & + & + \\
Acacia tortilis & Fabaceae & $\mathrm{T}$ & + & + & + \\
Albizia gummifera & Fabaceae & $\mathrm{T}$ & - & + & + \\
Allophylus abyssinicus & sapindaceae & $\mathrm{T}$ & - & + & - \\
Apodytes dimidiata & Icacinaceae & $\mathrm{T}$ & - & + & + \\
Balanites aegyptiaca & Balanitaceae & $\mathrm{T}$ & - & + & + \\
Calpurnia aurea & Fabaceae & $\mathrm{S}$ & - & + & + \\
capparis tomentosa & capparidaceae & $\mathrm{S}$ & - & + & + \\
Carissa edulis & apocynaceae & $\mathrm{T} / \mathrm{S}$ & + & + & + \\
Causerina equistifolia & casuarinaceae & $\mathrm{T}$ & - & + & + \\
Croton macrostachyus & Euphorbiaceae & $\mathrm{T}$ & - & + & + \\
dichrostachys cinerea & Fabaceae & $\mathrm{S}$ & + & + & + \\
Dodonaea angustifolia & sapindaceae & $\mathrm{T} / \mathrm{S}$ & + & + & + \\
Entada abyssinica & Fabaceae & $\mathrm{S}$ & - & - & + \\
Eucalyptus camaldulensis & Myrtaceae & $\mathrm{T}$ & - & + \\
\hline
\end{tabular}


Dessale Wasie and Fantaw Yimer: Effects of Integrated Soil and Water Conservation Practices on Woody Species Diversity, Structure and Regeneration in Southern Ethiopia

\begin{tabular}{llllll}
\hline Botanical Name & Family & category & Open grazing & Closure area without SWC & Closure area with SWC \\
\hline Ficus sycomorus & Moraceae & $\mathrm{T}$ & - & - & + \\
Gravilia robusta & Proteaceae & $\mathrm{T}$ & - & - & + \\
Grewia bicolor & Tiliaceae & $\mathrm{S}$ & - & + & + \\
Grewia villosa & Tiliaceae & $\mathrm{S}$ & - & + & + \\
Leucaena leucocephala & Fabaceae & $\mathrm{T} / \mathrm{S}$ & - & - & + \\
Moringastenopetalla & moringaceae & $\mathrm{T}$ & - & - & + \\
Olea europeae & Oleaceae & $\mathrm{T}$ & - & + & + \\
Rhus natalensis & Anacardiaceae & $\mathrm{T} / \mathrm{S}$ & - & - & + \\
Sesbania sesban & Fabaceae & $\mathrm{T} / \mathrm{S}$ & - & - & 26 \\
Total & & & 7 & 17 & + \\
\hline
\end{tabular}

Table A2. List of species identified in the area closures with SWC their scientific and family names, frequencies (FR, \%), dominance (Do, $m 2$ ha-1), relative densities $(R D E, \%)$, relative frequencies ( $R F R, \%)$, relative dominance (RDO, \%), importance value index (IVI, \%).

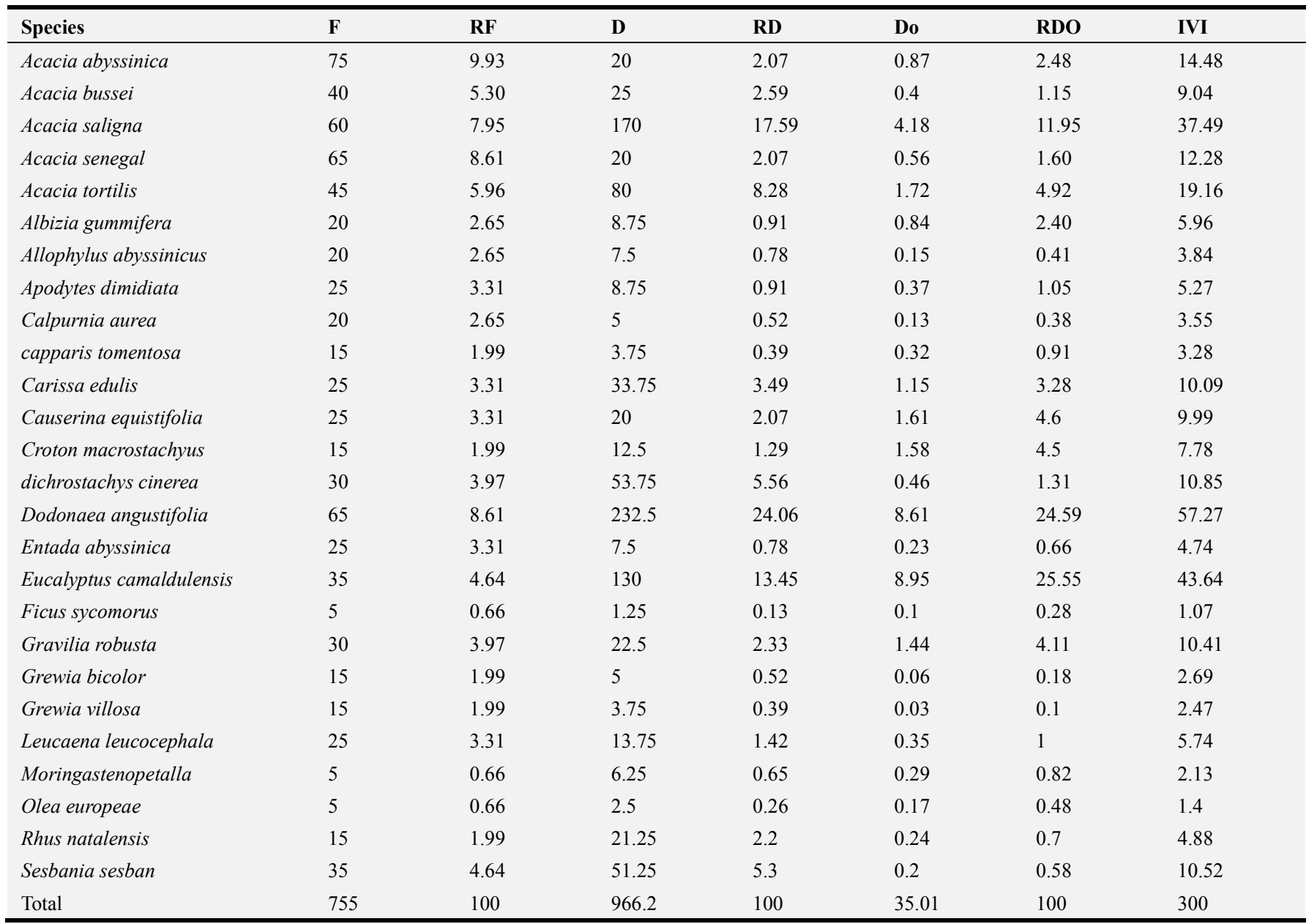

Table A3. List of species identified in the area closures without SWC their scientific and family names, frequencies (FR, \%), dominance (Do, $m 2$ ha-1), relative densities (RDE, \%), relative frequencies ( $R F R, \%)$, relative dominance (RDO, \%), importance value index (IVI, \%).

\begin{tabular}{|c|c|c|c|c|c|c|c|}
\hline Species & $\mathbf{F}$ & RF & D & RD & Do & RDO & IVI \\
\hline Acacia abyssinica & 25 & 5.49 & 8.75 & 2.60 & 1.12 & 7.42 & 15.51 \\
\hline Acacia bussei & 30 & 6.59 & 15 & 4.46 & 2.19 & 14.54 & 25.59 \\
\hline Acacia seyal & 20 & 4.40 & 7.5 & 2.23 & 0.98 & 6.46 & 13.09 \\
\hline Acacia tortilis & 95 & 20.88 & 177.5 & 52.79 & 2.96 & 19.63 & 93.29 \\
\hline Allophylus abyssinicus & 25 & 5.49 & 6.25 & 1.86 & 1.61 & 10.68 & 18.03 \\
\hline Balanites aegyptiaca & 10 & 2.20 & 2.5 & 0.74 & 0.48 & 3.17 & 6.11 \\
\hline capparis tomentosa & 15 & 3.30 & 3.75 & 1.12 & 0.29 & 1.90 & 6.32 \\
\hline
\end{tabular}




\begin{tabular}{llllllll}
\hline Species & F & RF & D & RD & Do & RDO & IVI \\
\hline carissa spinarum & 35 & 7.69 & 22.5 & 6.69 & 0.56 & 3.70 & 18.09 \\
Croton macrostachyus & 40 & 8.79 & 16.25 & 4.83 & 0.12 & 0.82 & 14.45 \\
dichrostachys cinerea & 35 & 7.69 & 18.75 & 5.58 & 0.40 & 2.67 & 15.94 \\
Dodonaea angustifolia & 50 & 10.99 & 33.75 & 10.04 & 1.12 & 7.42 & 28.44 \\
Entada abyssinica & 10 & 2.20 & 2.5 & 0.74 & 0.11 & 0.76 & 3.70 \\
Grewia bicolor & 20 & 4.40 & 5 & 1.49 & 0.77 & 5.07 & 10.95 \\
Grewia villosa & 10 & 2.20 & 3.75 & 1.12 & 0.40 & 2.67 & 5.98 \\
Olea europeae & 5 & 1.10 & 1.25 & 0.37 & 0.18 & 1.19 & 2.66 \\
Total & 455 & 100 & 336.25 & 100 & 15.09 & 100 & 300 \\
\hline
\end{tabular}

Table A4. List of species identified in the open grazing land their scientific and family names, frequencies (FR, \%), dominance (Do, m2 ha-1), relative densities $(R D E, \%)$, relative frequencies (RFR, \%), relative dominance (RDO, \%), importance value index (IVI, \%).

\begin{tabular}{|c|c|c|c|c|c|c|c|}
\hline Botanical Name & $\mathbf{F}$ & RF & D & RD & Do & RDO & IVI \\
\hline Acacia abyssinica & 15 & 8.823 & 5 & 3.279 & 7.569 & 63.91 & 76.01 \\
\hline Acacia bussei & 30 & 17.64 & 15 & 9.836 & 0.028 & 0.233 & 27.72 \\
\hline Acacia senegal & 25 & 14.70 & 7.5 & 4.918 & 1.912 & 16.14 & 35.77 \\
\hline Acacia tortilis & 55 & 32.35 & 108.7 & 71.31 & 0.015 & 0.126 & 103.7 \\
\hline Carissa edulis & 10 & 5.882 & 2.5 & 1.639 & 0.135 & 1.136 & 8.66 \\
\hline Dichrostachys cinerea & 10 & 5.882 & 3.75 & 2.459 & 0.114 & 0.96 & 9.31 \\
\hline Dodonaea angustifolia & 25 & 14.7 & 10 & 6.557 & 2.071 & 17.48 & 38.75 \\
\hline total & 170 & 100 & 152.5 & 100 & 11.84 & 100 & 300 \\
\hline
\end{tabular}

\section{References}

[1] WEF (World Economic Forum). 2010. Biodiversity and business risk-A global risks network briefing. Geneva, Switzerland.

[2] Vlek, PLG, Le BQ, Tamene, L.2008. Land decline in land-rich Africa. Center for development research 12: 596-598.

[3] Teshome, A., Rolker, D., De \& Graaff, J. 2012. Financial viability of soil and water conservation technologies in northwestern Ethiopian highlands. Applied Geography 37: 139-149.

[4] Hurni, H., Tato, K., \& Zeleke, G. 2005. The implications of changes in population, land use, and land management for surface runoff in the Upper Nile Basin Area of Ethiopia. Mountain Research Development 25 (2): 147-154.

[5] Daniel, D. 2002. Soil and Water Conservation Techniques and Strategies for Food Security and Poverty Alleviation. 12th ISCO Conference, Beijing.

[6] Lemma T., Menfes T., \& Fantaw Y. 2015. Effects of integrating different soil and water conservation measures into hillside area closure on selected soil properties in Hawassa Zuria District, Ethiopia. Soil Science and Environmental Management. 6: 268-274.

[7] Kebede W., Habitamu T., Efrem G. and Fantaw Y. 2015. Soil erosion risk assessment in the Chaleleka wetland watershed, Central Rift Valley of Ethiopia. Environmental Systems 4: 5.

[8] Ministry of Water Resources (MoWR). 2009. Rift Valley Lakes Basin Integrated Resources Development Master Plan Study Project. Phase 3: Draft Report J. Lake Hawassa SubBasin Integrated Watershed Management Feasibility Study. Hal crow Group Limited and Generation Integrated Rural Development consultants 1 (3): 4.
[9] Mendel University Project in Ethiopia (MENDELU). 2016. Degraded land rehabilitation as a base for sustainable management of natural resources, in HawassaZuryaWereda, SNNPR, Ethiopia.

[10] Lu, X., Xia, J. \& Jang, J. 2010. Diversity and composition of understory vegetation in tropical seasonal rainforest of Xishuangbanna, Southwest China. International Journal of Tropical Biology 59 (1): 455-463.

[11] Hedbergs, I., Friis, I., \& Persson, E. 2009. Flora of Ethiopia and Eritrea. Vol.1. Addis Ababa, Ethiopia, Uppsala, Sweden.

[12] Krebs, C. J.1999. Ecological methodology (2nd Ed.). University of British Colombia, Harper Collins, New York pp 98-215.

[13] Azene B. 2007. Useful trees and shrubs for Ethiopia. RSCU. Nairobi, Kenya. 550pp.

[14] Shannon, C. E., \& Weiner, W. 1949. The Mathematical theory of Communication. Illinois Chicago, USA.

[15] Kent, M. \& Coker, P.1992. Vegetation description and analysis. A practical approach. John Wiley and Sons, New York pp 365.

[16] Tesfaye, M. 2008. Soil conservation experiments on cultivated lands in the Maybar area, Wello region, Ethiopia. Research Report Soil Conservation Research Project 16. University of Berne, Switzerland.

[17] Zegeye, H., Teketay, D., \& Kelbessa, E., 2011. Diversity and Regeneration Status of Woody Species in Tara Gedam and Abebaye Forests, Northwestern Ethiopia. Journal of Forestry Research 22: 315-328.

[18] Kasim, K., Assfaw Z., Derero, A., Melkato, M., \& Mamo, Y. 2015. The role of area closure on the recovery of woody species composition on Degraded lands and its socioeconomic importance in central rift Valley area, Ethiopia. International Journal of Dev 5 (2): 3348-3358. 
Dessale Wasie and Fantaw Yimer: Effects of Integrated Soil and Water Conservation Practices on Woody Species Diversity, Structure and Regeneration in Southern Ethiopia

[19] Lemenih, M. \& Kassa, H., 2014. Re-Greening Ethiopia: History, Challenges and Lessons. Forests 5, 1896-1909.

[20] Lamprecht, H. 1989. Silviculture in Tropics: Tropical forest ecosystem and their species.

[21] Simon, S. \& Girma, B. 2004. Composition, structure and regeneration status of woody species in Dindin Natural forest,
Southeastern Ethiopia: An application for conservation. Ethiopian Journal of Biological Sciences 3: 15-35.

[22] Teketay, D., Lemenih, M., Bekele, T., Yemshaw, Y., Feleke, S., Tadesse, W., Moges, Y., Hunde, T., \& Nigussie, D. 2010. Forest Resources and Challenges of Sustainable Forest Management and Conservation in Ethiopia. Earthscan 4: 1963. 